\title{
Impact of Economic and Financial Literacy on the Spending Behaviour of Selected Public Servants in Lagos State Nigeria
}

\author{
ALEXANDER EHIMARE OMAKHANLEN, PAULINUS IKECHUKWU \\ IYIKA, PEACE ONYEDIKACHI CHIMEZIE, OLUSEGUN OSHO
}

\author{
Department of Banking and Finance, Covenant University, Ota, NIGERIA
}

\begin{abstract}
Low level of financial literacy among the young workforce has remained a lingering problem, especially in developing countries. This has been pointed out as one of the causes of poor personal financial management practice. This problem has hampered the efforts of various governments and institutions in this region geared towards financial inclusion and the overall economic wellbeing of the citizens. Most studies in this area focused on the financial literacy level of people rather than the effect on their behaviour. This study is an attempt examine the effect of financial literacy level on spending behaviour of 30 young adults from public sector organizations. The study employed the standard questions for assessing the knowledge level of respondents. The questions test their understanding of simple and compound interest,inflation and portfolio diversification. For the spending behaviour, thePlanned Behaviour Theory (PBT) proposed by Icek Ajzen (1985) as a theoretical framework for measuring spending behaviour using the respondents preparation of budget and personal pre-retirement savings account as proxies. Data was collected using a structured questionnaire. Descriptive statistics and multiple regression was used to analyze thedata. The result showed that there is a positive correlation between the level of financial literacy and the spending behaviour of therespondents. The less the knowledge of financial management the people have, the higher the risk of poor spendingbehaviour. The conclusion was drawn to say that more work is needed to equip the youth especially on the art of financial management.
\end{abstract}

Keywords: Financial literacy, spending behaviour, financial inclusion, retirement savings, budget, financial management

Received: August 4, 2020. Revised: December 12, 2020. Accepted: January 6, 2021. Published: January 11,2021

\section{Introduction}

Some studies have revealed that the ability of an individual to comprehend and utilize fundamental financial and economic principles plays a key role in achieving the proper level of economic wellbeing [15]. The above phenomenon has been observed by previous empirical research which showed that limited participation in the stock market for example is associated with lower levels of financial literacy [33]. In 2006, the Organization for Economic Cooperation and Development (OECD) published a policy brief tagged "the importance of Financial Education". Thereport reiterated the increasing importance of financial education, not just for investors alone but also for every average family deciding on how to maintain a balanced budget, purchase a home, fund children's education, and prepare for retirement (OECD, 2006). This work and subsequent ones by the OECD is helping to mainstream this subject among member and nonmember countries.

In 2017, for example, the application of the harmonized methodology or toolkit developed by the OECD-International Network on Financial Education (INFE) provided evidence of considerable scope for improvement in the financial literacy level across the G20 Countries. According to the report, the toolkit confirmed the importance of developing a sustainable national strategy on financial education that will cut across all groups of the population including young people [27]. The outcome from the survey also revealed that on average a low score for the Commonwealth Independent States (CIS) in comparison with the G20 member countries recorded higher scores. This created a source of concern for the OECD to work more closely with countries in this 
category to close the literacy gap for financial inclusion and sustainable economic development.

Narrowing down to Nigeria, the country still struggles with an approximately $40 \%$ gap in financial inclusion in comparison with its peer like South African with $11 \%$. This has been largely blamed on a lack of financial literacy among the citizens [2]. To underscore the importance of closing this gap by the government at all levels, the Central Bank of Nigeria $(\mathrm{CBN})$ declared that "Only when the vast majority of the Nigerian population is financially literate that they can participate in the formal financial system, by being aware of and taking advantage of its opportunities, get financially included and thereby contribute to the financial and economic development of Nigeria" (CBN). According to the CBN, an essential pillar of any consumer protection program is Consumer Education through 'financial literacy', defined as "the possession of knowledge and skills by individuals to manage financial resources effectively to enhance their economic well-being".

Generally, financial literacy experts believe that satisfactory skills and knowledge allow individuals to take advantage of the opportunities presented by a developed financial system as well as enable them to carry out appropriate risks appraisal before embarking on any spending or investing [27]. Suffice to say that the motivation for this study comes from the gap observed in the literature. Most work seem to focus on the level of financial literacy possessed by certain individuals or group but not many empirical evidence exist on the effect of financial literacy on actual financial behaviour of the people.

Therefore, this paper examined the intrarelationship between two component of financial literacy: knowledge and behavior of public servants in the selected state. On one hand,the financial literacy level of respondents was measured using standard questions which are designed to assess their understanding of basic concepts [15]. Secondly, planned behaviour(budget and pre-retirement savings plan) were adopted as proxies for spending behaviour. The methodology has become some sort of standard as seen in the literature. The understanding of three key financial concepts: interest rates, inflation, and portfolio risk diversification are tested by the methodology [10]. Though important studies like that of [3], found a positive relationship between financial knowledge and spending habit among staff of the faculty of management, Universiti Teknologi Malaysia. However, the study did not fully adopt the standard questions for assessing financial knowledge of the respondents. On this backdrop, it is therefore very crucial to embark on this study to contribute to literature using the standard score to evaluate this phenomenum in the context of civil servants who are likely the differ in behaviour than other category of workers in the chosen state

\subsection{Statement of Research Problem}

Low level of financial literacy among the citizens especially in developing countries have remained a lingering problem. Both researchers and policymakers pointed out that this is one of the causes of poor personal financial management practice. This problem has hampered the efforts of various governments and institutions in this region geared towards financial inclusion and the overall economic wellbeing of the citizens. As is common with the field of social sciences, there is a problem with the measurement of financial literacy and in particular its effect on the behaviour of the people. Suffice to say that most attempt in this area have focused on the financial literacy level possessed by people rather than the effect on their behaviour and overall wellbeing.

Secondly, studies which attempted to measure this variables failed to adopt the standard measure or theoretical basis [3]. On this backdrop, it is therefore very crucial to embark on this study by adopting the standard measures and the category of respondents in order to enrich the literature in this subject.

\subsection{Research Questions}

1. Do financially literate public servants have better spending behavior than the financially illiterate ones?

2. Does the interaction between marital status and financial literacy affect the spending behaviour of the workers? 


\subsection{Research Objectives}

The main objective of this study is to find out how the financial literacy level of public servants in the influences their spending behaviour.

1. To determine the effect of financial literacy level on the spending behaviour of public servants in Lagos State.

2. To determine the role of marital status and financial literacy on the quality of financial spending behaviour of workers in Lagos state

\subsection{Research Hypothesis}

1. H0: Financially literate workers do not have a better spending behavior that than the financially illiterate

2. H0: the marital status of financially literate workers does not affect their financial behaviour.

\subsection{Scope of the Study}

The study relied on primary data that were collected using semi-structured questionnaires distributed among 50 public servants who fall within the focused group. In all, 30 responses were obtained in the survey. The decision to choose public servants was predicated on an interview session with some credit officer in one of the established commercial banks in Nigeria who stated that many public servants, especially young oneswho obtain credits or salary advances from the banks end up spending them recklessly. They believe they are going to work for 35 years before retirement and therefore, there is time to be more prudent in the future. This has led to the vicious cycle of perpetual debt. The study, therefore, does not include other private-sector employees and older public servants.

\section{Literature review}

\subsection{Conceptual Review}

In the wake of the financial crisis and ensuing Great Recession, interest has burgeoned in programs seeking to enhance financial literacy due to its impact on individuals and households. For instance, the Organisation for Economic Co-operation and Development (OECD) has published a long list of reports on the importance of financial literacy and financial education programs [16]. The Central Bank of Nigeria $(\mathrm{CBN})$ defined financial literacy as the possession of knowledge and skills by individuals to manage financial resources effectively to enhance their economic well-being".

However, the OECD Survey Report 2017 has expanded this definition thus; financial literacy is a combination of awareness, knowledge, skill, attitude, and behavior necessary to make sound financial decisions and ultimately achieve individual financial wellbeing [23]. Before 2017, the definition was focused on skill and knowledge, however, two new aspects (attitude and behavior) were introduced to the subject [19]. While attitude focuses on an individual's propensity or disposition to savings as well as spending, on the other hand, behaviour refers to how individuals respond to the issue of financial planning/budgeting, saving, choosing products, paying bills, or retirement planning, etc. According to [19], knowledge entails understating of financial concepts like simple and compound interest, Inflation, time value of money, risks-returns relationship, and diversification. Three elements are therefore critical in the determination of the financial literacy level of an individual: his knowledge of financial concepts, behavioral pattern in terms of spending plan(budgeting) and overall attitude or disposition to the subject of finance.

In the literature, knowledge component is measured using the three questions which assesses the understanding of basic concepts seen as prerequisite for making sound financial decisions. These are understing simple and compound interest, inflation and the benefit of portfolio diversification [27]. The second component ; behaviour is generally measured by assessing whether people have budget, are able to pay debt and utilities without challenges. Lastly, the third component ;attitude focuses on personal traits such as preferences, beliefs, and noncognitive skills which clearly has impact of people's wellbeing [27]. 


\subsubsection{Financial Literacy as the offshoot of financial inclusion}

The Central Bank of Nigeria stated that only when the vast majority of the Nigerian populace is financially literate that they can participate in the formal financial system, by becoming aware of and taking advantage of opportunities, get financially included and thereby contribute to the financial and economic development of Nigeria. The above statement captures the nexus between financial literacy, financial inclusion, and ultimately economic development. The more knowledgeable people are about the financial products available to them, the more the likelihood that they will take advantage of the opportunities inherent in such products. Hence, financial literacy is a strong determinant of financial inclusion. This is in line with the definition of financial inclusion given by the World Bank Group. According to the Bank, financial inclusion refers to a situation when individuals and businesses have access to useful and affordable financial products and services that meets their needs; transactions, payments, savings, credit, and insurance delivered responsibly and sustainably [31]. The emphasis here is the proportion of individuals and firms that have access_and use financial services [19]. Improving access to financial products and services has also been the focus of the OECD especially among developing countries. According to a World Bank report, -1.7 billion adults - remain unbanked, and about half of unbanked people are mostly women, poor households in rural areas, or out of the workforce [31]. To further underscore the importance of this variable, it was identified, among the 7 enablers of the United Nations' 17 Sustainable Development Goals

World Bank Group considers financial inclusion as the key enabler in the reduction of extreme poverty, boosting shared prosperity, and has put forward an ambitious global goal to reach Universal Financial Access (UFA) by 2020, [30]. In 2010, 55 countries and many more others have made commitments to pursue financial inclusion, and over 60 countries have either launched or are developing national strategies to actualize this. When countries take a strategic approach in the developing national financial inclusion strategies involving financial regulators, telecommunications, competition, and education ministries, experience indicates that it affects the economic development of such countries by reducing poverty and deprivations.

\subsubsection{Financial Literacy, Financial Behaviour, and Socio-economic Variables}

The subject of savings as opposed to spending all of one's income or borrowings on consumption is well discussed in the literature [10]. The common financial product available and known to many especially in developing countries is a deposit savings account. On the other hand, aside from convenience and safety, it is not a financial asset with attractive return features; The average real rate of return on the savings accounts in developing countries (after inflation) has been negative in recent years. Holding assets other than a savings account thus serves as the simplest feature of informed savings behaviour. This was applied in a study of financial literacy and financial behavior conducted by [8]: Evidence from the Emerging Asian Middle Class. He found out that a large number of the middle class hold a savings account. Hence to measure financial literacy, he considered those who hold other forms of financial assets other than savings accounts as financially literate.

A simple definition of financial literacy was given by [14] as the ability to understand how money works, how one manages to earn or make it, how it is managed, and how it is invested. In particular, financial literacy refers to the set of skills and knowledge that allows an individual to make informed and effective decisions as it relates to their financial resources. One more definition of financial literacy is "the measure of how well an individual can comprehend and make use of personal finance-related information in their everyday life [13]. Traditional economic model of saving and consumption (spending) decisions implicitly assume that individuals are capable of formulating, executing, dissimulation of plans, and to undertake multifaceted economic calculations and decisions [16]. Yet, as [14]a few persons possess adequate financial knowledge to make and execute complex financial plans. Moreover, acquiring such knowledge is likely to come at a cost. There is an established link between illiteracy and financial problems. For example, 50\% of the people with problematic debts have a low level 
of literacy. Though this is a less researched subject than savings decisions according to [10], [12] believe that previous reiterated the correlation between financial literacy and debt burden. In the same vein, [10] found that financial literacy is negatively linked to debt. According to his findings, the less financially literate an individual is the more the chances of engaging in transactions or financial products with a high-interest rate without knowing it, pilling up debt. An example of this is a credit card or even products like soft loans and salary advances often extended to workers by some financial institutions to pay bills in anticipation of monthly salaries.

Symptoms of financial illiteracy include increasing rates of personal or household debt due to excessive credit card usage, consumer personal loans, and pursuing over-optimistic home loan obligations, reckless over-consumption, and foolish devotion to luxury goods [12] Misguided financial decisions such as poor spending habit cause financial difficulties, resulting in low financial and overall well-being [13]. Therefore, less knowledgeable people tend to incur more debt than those who are financially literate. While previous literature have focused on the external factors that are related to debt burden, for example, interest rate, inflation, taxes, mortgage price index, expected income, and GDP, [12] gave attention to behavioral factors that could plunge people into debt. This is rooted in the Planned Behavior Theory (TPB) as the underpinning theory for their study.

\subsubsection{Financial literacy, Spending Behaviour and Demographic factors}

Spending and consumptive behavior which is a function of the financial literacy level of an individual employee seems to have received less attention in the empirical literature. However, recently, researchers like [1], [12] have explored this subject area. The former found out that poor spending habit occasioned by lack of financial management skills creates problems for individuals in the future. This view is supported by earlier work of Idris et al which posited that reckless, unnecessary energy investment and reckless devotion to rapid schemes are associated with financial illiteracy and often lead to huge debt burden in the future [12]. The same view was expressed by [6]. According to them, each individual who can make the right decision regarding finance today will not be in a financial crisis in the future. They also show healthy financial behaviour and able to prioritize their needs, not their wants.

Spending habit was divided into three by Cummins et al (2009).

1. Planning concept; this refers to whether or not individuals have a spending plan or engage in impulsive spending

2. Savings concept; whether or not individuals set aside money for the rainy day

3. Purchasing essential goods/services; do individuals spend money on necessities or nonessentials items like luxury?

These three succinctly captures the yardstick to identify an individual's attitude to spending. [1] accurately captured this when they stated that the best way to manage one's income without entering into a financial crisis is to separate needs from wants. This can be achieved through planned spending on essentials rather than engaging in spontaneous or impulsive buying. [21] further identified four aspects of financial behaviour as follows;

1. Writing a financial plan/budget

2. Savings and investing

3. Spending

4. Controlling through the use of budget and actual spending

This is pointing in the same direction as Cummins's characteristics though with little modification.

Demographic variables like gender, marital status, age, or family dependants have been found to also influence how people spend money. For examples singles have been found to possess lower literacy level and are more prone to financial indiscpline and poorer overall wellbeing than married individuals [26]. Also, young adults between the ages 25 and 34 were found to have used loans with high costs [29]. In similar vien, [28] found that families with a child are less likely to show high financial literacy levels and good spending habit than those with more children. Same goes for families without dependent relatives in comparison to those with dependants. It obvious from the above that the nexus between financial literacy level, behaviour and demographic variables is well established in the literacture albeit with a few divergent views. 


\subsection{Theoretical Framework and Focus Group Selection}

A theoretical framework guides your research, determining what variables to measure, and what statistical relationship to expect. The traditional microeconomic approach to saving and consumption decisions, according to [15], suggests that a fully rational and well-informed person should spend less than his income in times of high earnings while saving to sustain consumption when income falls (e.g. after retirement). Their belief is predicated on the saving, consumption (spending), and indebtedness decisions theory developed in the life-cycle hypothesis by [18] and in the Permanent Income Hypothesis [9].The life-cycle hypothesis concludes that the younger people consume or spend more than their means by borrowing against future unearned income. The theory starts with the observation that, at various points in the life cycle, consumption needs and income are often unequal, thus younger people tend to have consumption needs that outweigh their income. These needs continue to be predominantly for accommodation, schooling, and luxury goods like gadgets and therefore they have little savings.

\subsubsection{Spending Behaviour and the Planned Behaviour Theory}

Like in most topics in the social and beharioural sciences, researchers face difficulties in accurately assessing the behavioral effect of financial literacy. To evaluate the impact of financial literacy on the spending behavior of individuals, however, researchers need information on variables other than the current levels of financial literacy of respondents [14]. This information includes habits like engaging in extra-budgetary spending, spending on nonessentials, etc. In this study, respondents were asked similar questions to determine whether they have a budget in place detailing how they intend to utilize their disposable income. This is in line with the Planned Behavior Theory (PBT) which was proposed by Icek Ajzen in 1985 through his article "A theory of expected behaviour from thoughts to actions." This emanates from the 1980 work of Martin Fishbein and Icek Ajzen called the theory of reasoned action, where they postulated a link between people's beliefs and behaviour. In other words, what people are aware of, their attitude and disposition about that affect their behaviour.

\subsection{Empirical Review}

Search for empirical evidence has shown that Nigeria,for example, suffers from pausity of studies in this area. However, a related study by [7] provides evidence of how the knowledge, skill, and experience of audit committee members affects the quality of financial reports to shareholders. They concluded that the qualifications of audit committee members should be considered seriously during their appointment to ensure effective, efficient, and quality financial reporting for informed decisionmaking. [24] found that the ability to read, analyze, manage, and communicate the personal financial conditions that affect material wellbeing is of utmost importance. Being able to manage money, keep track of personal finances, plan, choose financial products, and stay informed about financial matters enable the avoidance of financial disaster. Using sample consisting of 1,400 individuals living in Rio Grande do Sul, Brazil and descriptive statistics and multivariate analysis techniques to analyse their responses, [25] found that demographic variables like marital status, occupation, age, and squared age showed no statistically significant coefficients, indicating that they do not play a significant role in the financial literacy of the sampled individuals. This results, however, agree with the hypotheses that suggesting that married individuals, show higher financial literacy levels [5]

Another empirical study embarked upon by [42] found that unlike demographic variables, financial eductation,attitude and behaviour play significant role in the dtermination of the financial literacy level of young working adults in Malaysia. This study adopted the Planned Behaviour Theory and observed that many young people due to lack of financial knowledge exhibit poor attitude and behaviour which reflect in their financial behaviour. Another important study by [3] found a positive relationship between financial knowledge and spending habit among staff of the faculty of management, Universiti Teknologi Malaysia. However, this study did not fully adopt the 
standard questions for assessing financial knowledge of the respondents. On this backdrop, it is therefore very crucial to embark on this study to contribute to literature using the standard score to evaluate this phenomenum in the context of civil servants who are likely the differ in behaviour than other category of workers in the chosen state.

\section{Methodology}

The study adopted the standard measure for both the dependent(spending behaviour) and the indpenpendent variables(knowledge component of financial literacy and marital status of respondents). The dependent variable was measured by assessing whether or not the respondents prepare budget before embarking on spending and if they maintain voluntary pre-retirement savings plan.

Secondly, for measuring the financial literacy level of respondents, we deployed thestandard questions to asses the their understanding of basic financial concepts seen as a prerequisite for making sound financial decisions. These involve understanding simple and compound interest, inflation and the benefit of portfolio diversification [10,15,27].

\subsection{Model specification}

A simple linear model was specified for this study. The model tested the effect of the independent variables on the spending behavior of the respondents.

$S_{i}=a_{0}-b X_{i}+e_{i}, i=1, \ldots, n$.

Model Equations

$S_{i}=a_{0}+b f l_{i}+e_{i} \ldots \ldots \ldots \ldots \ldots \ldots . .1$

$S_{i}=a_{0}+b m s_{i}+e_{i} \ldots \ldots \ldots \ldots \ldots \ldots . .2$

Combining the effectors for $\mathrm{H}_{1}$, we have;

$S_{i}=a_{0}-b f l_{i 1}+b m s_{i}+e_{i} \ldots \ldots \ldots . .3$

Where $S_{i}=$ Spending behaviour proxied by the presence of spending budget or voluntary preretirement savings plan.

$a_{0}=$ constant,

$\boldsymbol{b}=$ coefficient of the effector,
$X_{i}=$ effector/independent variables,

$e_{i}=$ error term,

$f l=$ Financial Literacy,

$m s=$ marital status.

\subsection{Model Estimation}

Using descriptive analysis and multiple regression analysis, the data collected was analyzed. Descriptive statistics gives at a glance the level of financial literacy and spending behavior which can be seen in terms of mean, standard deviation, maximum and minimum scores, etc. The next test was regression analysis deployed to find out the outcome effect of the independent variables on the financial behaviour of the respondents. Initial data testing e.g. Normality, linearity, multicollinearity, and heteroscedasticity testing was done to determine the robustness and suitability of the data before testing the model using the regression technique.

$S_{i}=a_{0}-b f l_{i 1}+b m s_{i}+e_{i} \ldots \ldots \ldots \ldots \ldots \ldots \ldots \ldots . .3$

The dependent variable $S_{i}$ is a dichotomous or binary variable taking values between 1 and 0 .

Two out of the four (4) aspects of financial behaviour identified by [21] are writing a financial plan/budget and savings plan. In this study, therefore, both are used as a proxy for financial behaviour. One (1) is assigned to a worker who has a budget and those who has a voluntary pre-retirement savings plan and zero (0) if otherwise denoting a high risk of overspending through impulse spending. $f l$ is measured using basic Lusardi and Mitchell score. The three (3) questions testing respondents' knowledge of key economic indices: interest rate, inflation, and risk diversification. Weight were assigned to these proxies thus: Interest rate and inflation questions are scored 25 each while the question on risk is assigned 50. Any respondents who got all 3 questions correctly scores 100 . If question 1 and 3 correctly he or she scores 75 and so on. Control variable; Marital status $m s_{i}$ was assigned one (1) for married and zero (0) if otherwise. 


\subsection{Technique for Data Collection}

Primary data was collected through semi structured questionnaires distributed among 50 public servants in Lagos state who fall within the focused group. 30 responded to the survey. The choice of public servants is predicated on an interview session with a credit officer in one of the established commercial banks in Nigeria, it was gathered that public servants could get loan approval easier compared to private sector workers. This was attributed to the jobsecurity; these public servants usually stickto the job until they retire. Therefore, it logical to select respondentsfrom this sector as their job and income level are relatively stable and predictable. Aside from this consideration, workers who are marriedwere selected as well

\section{Data presentation}

\subsection{Analysis and Discussion of result}

\section{Table 1: Details of respondents in the structured survey}

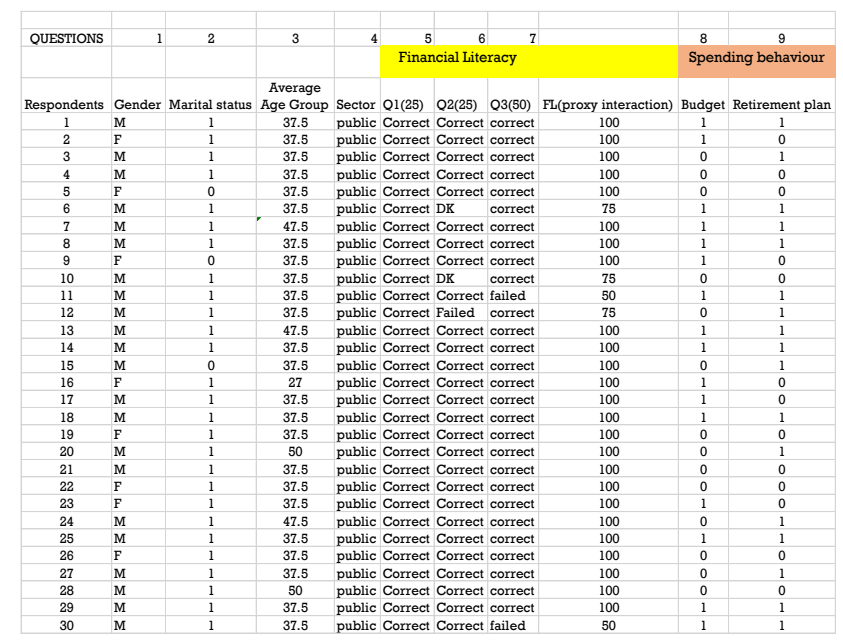

Source: Researcher's data set from survey

Table 2 Financial behaviour using budget as proxy

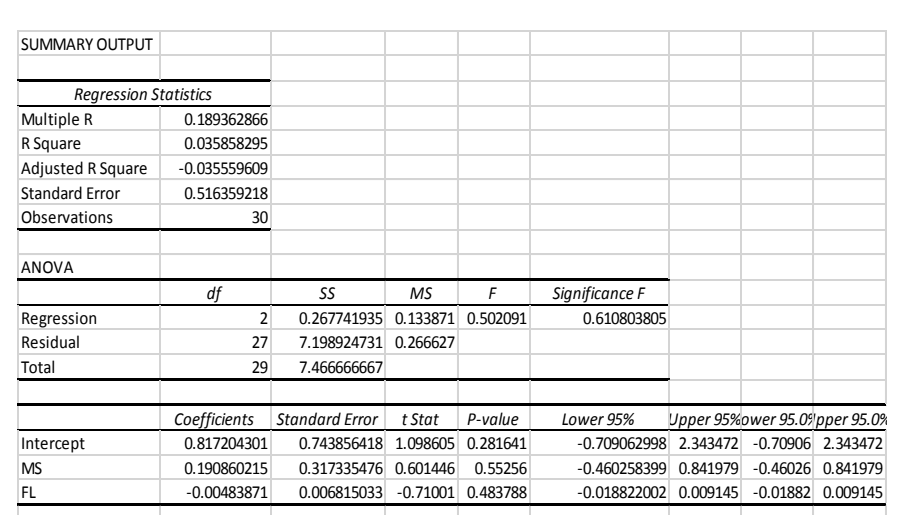

Table 3 Financial behaviour using preretirement savings as proxy

\begin{tabular}{|c|c|c|c|c|c|c|c|c|}
\hline \multirow{2}{*}{\multicolumn{9}{|c|}{ SUMMARY OUTPUT }} \\
\hline & & & & & & & & \\
\hline \multicolumn{9}{|c|}{ Regression Statistics } \\
\hline Multiple R & 0.274440288 & & & & & & & \\
\hline R Square & 0.075317472 & & & & & & & \\
\hline Adjusted R Square & 0.00682247 & & & & & & & \\
\hline Standard Error & 0.502284704 & & & & & & & \\
\hline Observations & 30 & & & & & & & \\
\hline \multicolumn{9}{|l|}{ ANOVA } \\
\hline & $d f$ & SS & $M S$ & $F$ & Significance $F$ & & & \\
\hline Regression & 2 & 0.55483871 & 0.277419 & 1.099605367 & 0.347456786 & & & \\
\hline Residual & 27 & 6.811827957 & 0.25229 & & & & & \\
\hline \multirow[t]{2}{*}{ Total } & 29 & 7.366666667 & & & & & & \\
\hline & Coefficients & Standard Error & tStat & $P$-value & Lower $95 \%$ & \multicolumn{3}{|c|}{ Upper $95 \%$ wer $95.0 \%$ pper $95.0 \%$} \\
\hline Intercept & 1.139784946 & 0.723580965 & 1.5752 & 0.1268564 & -0.344880559 & 2.62445 & -0.34488 & 2.62445 \\
\hline MS & 0.206989247 & 0.308685796 & 0.67055 & 0.508202928 & -0.426381688 & 0.84036 & -0.42638 & 0.84036 \\
\hline $\mathrm{FL}$ & -0.008064516 & 0.006629274 & -1.2165 & 0.23432223 & -0.021666663 & 0.005538 & -0.02167 & 0.005538 \\
\hline
\end{tabular}

\subsection{Discussion of Result}

\section{The hypotheses are as follows:}

H0: Financially literate workers do not have a better spending behavior that than the financially illiterate

H0: Financially literate workers who are married are more likely to make better quality financial decisions than the unmarried ones

Table I shows the data set gotten respondents. The average age is approximately 39 years. That is line with the objective of the study which is targeted at the youth who still have years ahead to work in the public service bearing in mind the compulsory retirement age of 60 years. They form the productive workforce whose collective financial wellbeing will contribute to the aggregate economic wellbeing of any country. 
It can be seen that 25 out of 30 respondents which is equivalent to $83.33 \%$ of total respondents were able to answer the 3 questions for the financial literacy test correctly. Only about 3 respondents answered Q1 and Q3 correctly and 2 got Q1 and Q2 representing 10 and $6.67 \%$ respectively.

$90 \%$ of respondents are married while $73.33 \%$ are male while the rest are female.

The table also shows that 16 out of 30 respondents have no monthly financial budget. This represents $53.33 \%$ of the total respondents. In other words, $46.67 \%$ of the respondents have a relatively high level of risk of engaging in unplanned spending monthly. Also, $43.33 \%$ do not have any voluntary savings toward retirement. Juxtaposing these statistics, the high literacy level of the respondents may have contributed to a higher number of workers $(53.33 \%$ and $56.67 \%$ ) respectively who both maintain a monthly budget and have an existing retirement savings plan.

Looking at the multiple regression analysis used to test the model, note that though with a low $\mathrm{R}^{2}$ forboth budget and Voluntary RSP as a proxy; due to the dichotomous nature of the variables, the coefficients for financial literacy is negative indicating a linear relationship with inverse proportion. The negative slope shows that the more financially literate an individual worker is, the lower the chances of engaging in negative behaviour associated with money like unplanned spending.

It can be safely concluded the healthy financial behavior exhibited by the respondent is impacted by their level of literacy and vice versa. In order words, people who lack awareness, knowledge, skill, and the right attitude to managing money are likely to engage in impulsive spending especially on non-essentials. Especially the young worker in public service who believes his job is secure and still has a lot of years to work before retirement.

On an individual level, having a monthly spending plan will serve as immunity against poor /low-quality spending decisions. Therefore, deliberate effort is needed to put down what is needed not just what is wanted. This will prevent to a large extent impulsive spending behaviour.

The model can be estimated thus;
Monthly Budget $S_{i}=0.8172_{i}-$
$0.0048 f l_{i 1}+0.1909 m s_{i}+0.516359218$

Retirement Savings Plan $S_{i}=1.1398_{i}-$ $0.0081 f l_{i 1}+0.2069 m s_{i}+0.502284704$

\section{Conclusion}

It is evident from the data and literature that financial literacy is key requitement effective management of one's financial resources for his or her wellbeing both while in active working period and during retirement. The surest way to financial freedom is to equip oneself with the necessary knowledge, experience, skills, and ability to organize, manage, and control financial affairs. With good financial literacy, a person can plan and manage his or her financial affair prudently without running into financial crisis such bankruptcy and heavy debt burden.

\subsection{Recommendation}

The following recommendation is key to various stakeholders:

1. In the global space, the OECD, UN, IMF the World Bank,Africa Development Bank(ADB) and other multilateral agencies should endeavor to design policies aimed at improving the financial literacy level of member states and partners. Focus should be on demographic characteristics of the people.

2. In Nigeria, governments' efforts especially the CBN should fashion out various development finance initiatives targeting the youths with a view to catching them young. A good approach could be embark on youth initiatives using the entertainment industry to champion the course of savings and prudent spending culture. The youth nowadays are better captured through unconventional channels like social media rather than the formal education systems.

3. Parents and guidians should make it a priority to inculcate the right knowledge, attitude and behaviours regarding money on their children and wards respectively. Not only charity, but 
spending, savings , and investment culture begins from home.

\section{Author's Contribution}

1. Alexander Ehimare Omankhanlen; Supervision.

2. Paulinus Ikechukwu Iyika; Writing-Original \&Draft, Methodology Review

3. Peace Onyedikachi Chimezie; Conceptualization \& Editing.

4. Olusegun Osho; Literature.

\section{Acknowledgments:}

We want to acknowledge Covenant University Centre for Research, Innovation and Development (CUCRID) for provision of enabling environment for this research.

\section{References:}

[1] Andriani D. and Nugraha, N(2018). Spending Habits and Financial Literacy Based on Gender on Employees . IOP Conference Series : Material Science and Engineering 407.012089 .

[2] Awodipe, $T$ (2019). Poor financial literacy is responsible for the gap in Nigeria's financial inclusion. Retrieved from: https://guardian.ng/guardianwoman/poor-financial-literacy-is-responsible-for-the-gapin-nigerias-financial-inclusion/

[3] Azmi,N.F. and Ramakrishnan(2018).Relationship Between Financial Knowledge and Spending Habits among Faculty of Management's Staff. Journal of Economic Info (JEI) www.readersinsight.net/jei

[4]Ajzen,I.(1985).From Intentions To Actions: A Theory of Planned Behavior . In J.Kuhl \& J. Beckman(Eds.)Action-control: from cognition to behavior(Pp.11-39). Heidelberg: Spriger.

[5] Calamato, M. P. (2010). Learning financial literacy in the family. Unpublished master's thesis. The Faculty of the Department of Sociology, San José State Universit.

[6] Chinen K and Hideki.(2012). Attitude and Background on Personal Finance Ability: A Student Survey in the United State. International Journal of Management, 33-45.
[7] Eriabie, Sylvester O. and Adeyemo, Kingsley A (2016) The Impact of Financial Literacy and Frequency of Meetings of Members of Audit Committee on Financial Reporting Quality in Nigerian Quoted Companies. Journal of Accounting, Finance, and Auditing Studies, 2 (2). pp. 122.

[8] Faboyede, Olusola Samuel and Mukoro, D. O. (2012) Financial Statement Insurance: Restoring Investor Confidence in Nigerian Banks. Research Journal of Finance and Accounting, 3 (4). pp. 140-150. ISSN 2222-1697 (Paper) ISSN 2222-2847

[9] Friedman,M. (1957). The Permanent Income Hypothesis. A Theory of Consumption Function. Princeton University Press. Pp.20-37.

[10] Grohman, A. (2017). Financial literacy and financial behavior: Evidence from the emerging Asian middle class. Pacific-Basin Finance Journal, 48, 129-143. doi: 10.1016/j.pacfin.2018.01.007

[11] Horne, J. V. (n.d.). Fundamentals of Financial Management. Englewood Cliff N, J: Prentice-Hall.

[12] Idris, N., Yazid, Z., Faique, F., Daud, S., Ismail, S., Bakri, M., \& Taib, N. (2016). Financial Literacy and Debt Burden Among Malay Youth Workers in Malaysia. Advanced Science Letters, 22(12), 4288-4292. DOI: 10.1166/asl.2016.8130

[13] Kim,J.(2001). Financial knowledge and Subjective and Objective Financial Well-being. Consumer Interest Annual,Pp.1-3.

[14] Lusardi, A and Mitchell, O.S (2008).Planning and Financial Literacy: How Do Women Fare? . National Bureau of Economic Research(NBER) Working Paper 13750 Issued January ,2008.

[15] Lusardi, A and Mitchell, O.S (2011).Financial Literacy Around the world : An Overview. National Bureau of Economic Research(NBER) Working Paper Issued June,2011.

[16] Lusardi, A and Mitchell, O.S (2018). Assessing the Impact of FinancialEducation Programs: A Quantitative Model. Pension Research Council Working Paper Pension Research Council.

[17] Marsh, W., \& Kunlanslay. (n.d.). Case Problems in Financial Management. Prentice-Hall.Monticone, C. (2018). Financial Literacy In The CIS And At A Global Level. Paris: Oecd. 
[18] Modigliani,F. and Brumberg, R.H.(1954).Utility Analyis and the Cosumption Function: an interpretation of cross-section data. In K.K.Kurihara ed.,Post Keynesian Economics, Rutgers University Press,New Brunswick,pp.388-436.

[19] Monticone,C. (2018). Financial Literacy in the CIS and at a Global Level. OECD-Russia Global Symposium “ Advancing financial literacy global : implementation and innovation" October,2018, Moscow. Mottola, G. R. (2013). In our best interest: women, financial literacy, and credit card behavior. Numeracy, 6(2)

[20] Nur Hafidzah Idris, Z. A. (2016). Financial Literacy and Debt Burden Among Malay Youth Workers in Malaysia. Advanced Science Letters, 4288-4292.

[21] Nyoman Trisna Herawati, M. C. (2018). Factors that influence Financial Behaviour Among Accounting Students in Bali. Journal of Business Administration

[22] OECD(2006) Policy Brief : The importance of Financial Education,. July,2006.

[23] OECD(2017). G20/OECD INFE Report on Adult Financial literacy in G20 Countries.

[24] Olusola, .S., and Egbide, B., and Oyewo, B. and Faboyede, A. (2015) Financial Literacy Education: Key to Poverty Alleviation and National Development in Nigeria. European Journal of Accounting Auditing and Finance Research, 3 (1). pp. 20-29. ISSN 2053-4086.

[25] Potrich, A.C.G, Vieira, K. M, \& Kirch,G.(2015).Determinants of Financial Literacy: Analysis of the Influence of Socioeconomic and Demographic Variables. R. Cont. Fin. - USP, São Paulo, Vol. 26, No. 69, Pp. 362-377, November, 2015.
[26] Research, R. M. (2003). Survey of adult financial literacy in Australia. ANZ Banking Group. Retrieved on April 16, 2013, from http:// www.anz.com/Documents/AU/Aboutanz/AN 5654.

[27] Salvatore, A., Franceschi,F., Neri,A.,and Zanichelli,F.(2017). Measuring the financial literacy of the adult population: the experience of the Bank of Italy. IFC Satellite Seminar at the ISI World Statistics Congress on "Financial Inclusion".

[28] Servon, L. J., \& Kaestner, R. (2008). Consumer financial literacy and the impact of online banking on the financial behavior of lower-income bank customers. Journal of Consumer Affairs, 42(2), 271-305.

[29] Scheresberg, C. B. (2013). Financial literacy and financial behavior among young adults: evidence and implications. Numeracy, 6(2UN's Sustainable Development Goals Report,September, 2015.

[30] UNCTAD (2015). Access To Financial Services As A Driver For The Post-2015 Development Agenda. Policy Brief No.35 September,2015.

[31] Worldbank(2018). UFA2020 Overview : Universal Financial Access by 2020. Accessed from https://www.worldbank.org/en/topic/financialinclusion/bri ef/achieving-universal-financial-access-by-2020

[32] Yong,C.C., Yew,S.Y \& Wee,C.K.(2018). Financial Knowledge, Attitude and Behaviour of Young Working Adults in Malaysia. Institutions and Economies Vol. 10, No. 4, October 2018, pp. 21- 48

[33] Yoong, J.(2010). Financial Literacy and Stock Market Participation : Evidence from the RAND American Life Panel. Pension Research Council Working Paper No.201029. Nov.2010.

\section{Creative Commons Attribution License 4.0 (Attribution 4.0 International, CC BY 4.0)}

This article is published under the terms of the Creative Commons Attribution License 4.0 https://creativecommons.org/licenses/by/4.0/deed.en_US 